Abstracta Iranica Iranica

Revue bibliographique pour le domaine irano-aryen

Volume 27 | 2006

Comptes rendus des publications de 2004

\title{
Les Kurdes Ardalân entre la Perse et l'Empire ottoman. Paris, Geuthner, 2004, 226 p.
}

\section{Florence Hellot}

\section{Q OpenEdition}

1 Journals

\section{Édition électronique}

URL : http://journals.openedition.org/abstractairanica/6077

DOI : 10.4000/abstractairanica.6077

ISSN : 1961-960X

Éditeur :

CNRS (UMR 7528 Mondes iraniens et indiens), Éditions de l'IFRI

\section{Édition imprimée}

Date de publication : 15 mai 2006

ISSN : 0240-8910

Référence électronique

Florence Hellot, « Les Kurdes Ardalân entre la Perse et l'Empire ottoman. Paris, Geuthner, 2004, 226 p. », Abstracta Iranica [En ligne], Volume 27 | 2006, document 225, mis en ligne le 02 janvier 2007, consulté le 25 septembre 2020. URL : http://journals.openedition.org/abstractairanica/6077 ; DOI : https://doi.org/10.4000/abstractairanica.6077

Ce document a été généré automatiquement le 25 septembre 2020.

Tous droits réservés 


\title{
Les Kurdes Ardalân entre la Perse et l'Empire ottoman. Paris, Geuthner, 2004, 226 p.
}

\author{
Florence Hellot
}

1 Cet ouvrage est le résultat d'une fructueuse coopération entre Sheerin Ardalan, qui a mené des recherches passionnées sur l'histoire de sa famille et le professeur Jean Calmard, qui l'a guidée dans ses recherches et qui a publié ce travail après que la maladie a emporté Sheerin Ardalan. Il aborde l'histoire de la principauté des Kurdes Ardalan, histoire tumultueuse en raison de sa situation géographique, aux confins des empires perse et ottoman. Centrée autour de la ville de Sena / Sanandaj, la principauté des Ardalan dut constamment défendre son autonomie et l'intégrité de son territoire. Elle est évoquée ici à partir du $9^{\mathrm{e}} \mathrm{s}$. de l'ère chrétienne, comme l'une des quatre principautés reconnues en Perse. Elle apparaît plus clairement dans l'histoire lors de l'avènement des Safavides et, surtout, à l'époque de Karim Khan Zand (1750-1779) qui apprécia Khosrow II Ardalan, passé dans l'histoire sous le nom de Khosrow II le Grand. C'est ce prince qui donne le ton à l'ouvrage, avec la finesse, la recherche de la paix et la spiritualité dont il fit preuve (les Ardalan étaient de religion yarsanie). Chaque lecteur, dans ce livre très fouillé et enrichi de longues et précieuses notes, pourra suivre l'évolution d'une principauté officiellement disparue en 1867, ainsi que celle de ses rapports avec les dynasties de Perse et de l'Empire Ottoman aux $17^{\mathrm{e}}$ et $18^{\mathrm{e}}$ siècles.

\section{INDEX}

Thèmes : 4.5. Histoire des kurdes 
AUTEURS

FLORENCE HELLOT

CNRS - Paris 